\title{
Аушан Крцуновић*
}

\section{Павлова идеја „новог човјека“ и трансхуманизам}

„[...] свуците старога човјека с дјелима његовијем, и обуците новога, који се обнавња за познање, по обличју онога који га је саздао.“ (Кол., 3. 9-10)

„Човјек је биће које постоји у односу, настаје кроз однос и постиже своју пуноћу динамичким односом.“ (Митрополит Амфилохије)

Схватање ьудског живота као непрекидног кретања „од старог ка новом човјеку“ јеАна је оА кьучних антрополошких оАреАница коА апостола Павла. Аинамика човјековог напредовања и обнавьања, с једне стране, има своје исходиште у човјековој боголикости, док се, с Аруге стране, она одвија „По обличју онога који га је саздао“. Будући да је човјек вјерна слика свог сазАатеља, он је на неки начин увијек испреА и изнаА самог себе. Аругим ријечима, ако то значи да „човек поседује неискорењиву тенденцију Аа себе постави у известан однос према Апсолутном, према идеацу, према послеАњој истини, према суштаству бића“, тер ьудске природе који се огмеда у сталној човјековој тежњи ка усавршавању

\footnotetext{
*ОАсјек за филозофију, Универзитет Црне Горе, Црна Гора (dusan.k@ucg.ac.me)

${ }^{1}$ Вишеславцев, Вечно у руској философији, 153. У наставку, Вишеславцев поентира тезом: „Појмити човека значи појмити његов однос према Богу“. Јевтић, у предавању „Стари и нови човек у Цркви“, истиче Аа је „[...] човек као мичност - као жива слика Божија - позван Аа динамички учествује и у божанскјом тројичном животу и тиме обогаћује то своје биће.” „Христос је Аонео ову новину зато што је као Бог постао човек, и у Себи као Богочовеку поставио човека на нови начин, у нови однос са Собом Аовео ьудску Природу, али такође и Себе, Своју божанску природу, по новоме сјединио са човеком.“ „Хришћански живот је, у живом православном искуству, стална динамика и стално кретање од старога ка новоме човаку“.
} 
и обогаћивању. ${ }^{2}$ Претпоставка тог себепостављања човјека у динамички оАнос према божанској стварности - које објашњава и ону, човјековој природи инхерентну тежњу ка самопревазимажењу - јесте слобода. У патристичкој

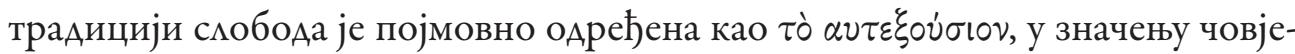
кове самовласности и слободе самоодређења и самоопредјењења.

Формулишући човјеково самопостављање према божанској стварности (на основу божанског самопоставьања према човјечанској стварности) на један сасвим нов начин, хришћанска антропологија је ујеАно Аала оквир за разумијевање и вредновање динамике ьудског живота као кретања „оА старог ка новом човјеку“. У критичку перспективу те чувене павловске формуле могу се поставити и Аруге велике европске хуманистичке традиције са својим идејама човјека и визијама његовог напретка. Једна оА тих традиција која је релативно неАавно ступила на позорницу европске интелектуане културе је и тзв. „трансхуманизам“. 3 Ријеч је о савременом интелектуалном, културном, аци и идеолошком покрету чији се експоненти, volens nolens, служе идејама хришћанске антропомогије. Али, супротставьајући се традиционалним вјерским погледима на човјека које сматра препреком истинском превладавању ограничења и слабости човјекове природе, трансхуманизам сматра да ће проблем ьудске природе бити ријешен онда када се „превазиђе (lat. trans) оно ьудско (lat. bumanum)““ уз помоћ технологије. Тиме Павлова мисаона фигура о старом и новом човјеку улази у полемички однос са идејом „пост-хуманог човјека“ у трансхуманизму.

Апостол Павле је предмет великог интересовања водећих европских фимософа које је достигло такве размјере Аа се Аанас говори о „Павловом обрту“" у савременој философији. Философска интересовања за читање и тумачење Павлових посланица мотивисана су, између осталог, тиме што је његова мисао универзалистичка и неконформистичка, чак и „субверзивна“ за све вцадајуће поретке и Аискурсе моћи. КаАа тражи оА свог аудиторијума: „Не саображавајте се овоме вијеку, него се преображавајте обновьењем ума свог“, онда он поставьа сваког човјека преА захтјев који му налаже промјену, преобра-

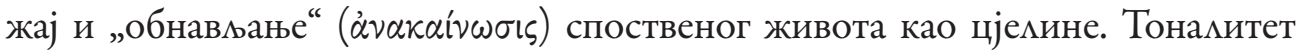
овог апостолског императива, који оАзвања у његовим посланицама, открива свијест о Аубокој онтолошкој кризи у којој се налази свијет „који межи у зму“.

\footnotetext{
2 Види: Митрополит Амфимохије, „Суочавање божанске и ьудске егзистенције, 160.

3 За одличан преглеА појма и историјата види: Heil, “Trans- und Posthumanismus”.

${ }^{4}$ Schmaus, "Nietzsches letzter Mensch als transhumanistische Dystopie", 207.

${ }^{5}$ Delahaye, "The Philosophers' Paul".
} 
Тај тоналитет упозорава на ургентност духовног и егзистенцијалног одговора на стање онтолошко-космолошке кризе која најавьује, колико неминован томико и непредвидьив крај „обличја овога свјета“. Живот у том неодређеном времену које је преостало човјеку преА есхатон захтијева будност и сталну Аинамику обнављања, јер у оном „како“ начина живота вјерујућег човјека пружа се једини одговор на есхатолошку неизвјесност оног „када“.

С тим у вези, разноврсне философске актуализације апостола Павла у савременој фимософији израз су трагања за теоријским и практичним одговорима на Аруштвену и политичку кризу, на кризу животног смисла и дезоријентацију савременог човјека. Та дезоријентација најАрастичније се манифестује као криза човјековог самосазнања. Обезврјеђивањем свих колективних форми идентитета (вјерског, цивилизацијског, национацног, породичног, језичког) покренут је процес индвидуализације идентитета, који је потом у наше вријеме довео и Ао проблематизације самог ьудског идентитета као таквог.

То је историјски контекст у коме је настао и развијао се интелектуанни покрет трансхуманизма, инспирисан просвјетитеьским секуларним хуманизмом, Ничеовом идејом Натчовјека и савременом биотехнологијом. Наиме, у секуАарном хуманизму просвјетитељства, из којег исходи сама идеја напретка, кретање оА старог ка новом човјеку је описано као „измазак и стања самоскривњене незремости“. 6 То је стање кад се препуштамо туђем вођству, спољашњем ауторитету, без употребе властитог разума који има природну свјетлост да нам освијетли пут и моћ Аа испитује мегитимност сваког ауторитета. Аакле пут оА старог ка новом човјеку овдје је описан као просвјећивање човјека Аа се служи властитим критичким разумом. То значи раскидање веза са традицијом и комективним идентитетима, раскорјењивање или истргнуће из властите културе (схваћене као партикуларне хуманости), у правцу приближавања идеји неке апстрактне, универзалне хуманости и космополитског грађанства.

С Аруге стране, крајем XIX вијека Фрилрих Ниче предлаже алтернативу, како платоновско-хришћанском тако и просвјетитеьском хуманизму. Иако је био жестоки критичар апостола Павца, апостолова опозиција између старог и новог човјека код Ничеа је формулисана као опозиција између Посьедњег човјека и Натчовјека. „Човјек је нешто што треба да буде превлаАано“, каже његов Заратустра. Циь тог превладавања или самопревладавања је фамозни Übermensch. И^и, како ће рећи Заратустра:

\footnotetext{
${ }^{6}$ Kant, „Odgovor na pitanje: Što je prosvjetiteljstvo?“, 33-42. Када Имануем Кант каже да је човјек „ОА сувише чворноватог Арвета направьен“, то значи Аа се идеални кик човјека који се оА материјала ьудске природе може истесати, не налази „на небу“ већ у самом човјеку и да његово „тесање и вајање“ подразумијева процес образовања.
} 
Čovek je uže razapeto između životinje i natčoveka - uže nad provalijom. Opasno prelaženje, opasno putovanje, opasno osvrtanje, opasno strpljenje i zastajanje. Veliko u čoveku jeste to što je on most a nije svrha: kod čoveka se može voleti to što je on prelaz i zalazak.

Ово кретање ими прелажење човјека који треба Аа буде превладан на путу ка Натчовјеку, схваћено је не као процес интитуционализованог образовања и васпитања, већ као умјетнички креативан процес, као слободно само-стварање човјека. У најбољем скучају, свако истинско образовање за Ничеа је самообразовање које је ујеАно и стално самопревцадавање човјека према мику Натчовјека. То значи афирмацију човјекове необуздане стваралачке индивидуалности коју сваки образовни систем и Аруштво желе Аа укроте и укотве. А^и, по Ничеу „човјек је још неустановњена/неукотвьена животиња“ (das noch nicht festgestellte Tier), ${ }^{8}$ он је неодређен, недефиньив, нема природу која га детерминише. Но, Аок с јеАне стране он не може да живи са том неодређеношћу, дотме, с Аруге стране, свако је самоодређивање ујеАно и једностраност која изневјерава човјекову исконску слободу и отвореност. Стога ниједан начин егзистенције којим је човјек себе одредио није коначан, па мора бити поново разбијен, јер човјек је мост, прелазак и пролазак ка нечем вишем оА њега самог - ка Натчовјеку. Ко је Натчовјек?, ми то не сазнајемо прецизно оА Ничеа, али зато много више сазнајемо од његовог Заратустре ко је онај који не треба Аа будемо - „посьедњи човјек“, који је много извјеснија ацтернатива оА пута ка Натчовјеку.

У спрези ових идеја трансхуманизам види крајње рјешење за проблем човјека. Кредо трансхуманиста је да се захваьујући напретку науке и биотехнологије могу остварити стари снови и идеали homo religiosus-а о продуженом животном вијеку без болести, патње и старења, о животу испуњеном задовољством и срећом, о проширењу човјекових интелектуанних и психо-физичких способности. У том циљу, трансхуманизам смијера на оптимизацију и унапређење биолошки индиспониране, крхке, рањиве и застарјеме ьудске природе путем технолошке моћи. ЈеАном ријечју, трансхуманизам смијера на оно што слови као „ьудско побољшање“ (buman enhancement) средствима технологије.

На први погмеА, хришћанска теологија и трансхуманистичка техномогија, смијерајући на побољшање човјека, имају исти циь, иако им се разАикују путеви којим настоје Аа Аођу до тог зајеАничког циља. Аок хришћанска теологија учи Аа се Ао тог циља долази путем духовних пракси и Божијим Аје-

\footnotetext{
${ }^{7}$ Niče, Tako je govorio Zaratustra, 46.

${ }^{8}$ Niče, Sone strane dobra i zla, frg. 62.
} 
мовањем, Аотле трансхуманизам заговара примјену технологије, одбацујући сваки супранатурализам. Својеврсни је парадокс то што трансхуманизам, Аок секуларизује хришћанску идеју човјека, истовремено „манифестује важну димензију слике Божје (imago Dei) у нашој цивимизацији: димензију креативности и преображајности“.?

Занемаримо ми приговоре Аа трансхуманизам „отјеловьује антропомошку утопију“, ${ }^{10}$ чији је циљ ничеовски „технолошки конструисани Übermensch“, ${ }^{11}$ не може се избјећи питање човјековог идентитета у Павцовом кретању оА старог ка новом човјеку и у трансхуманизму који најавьује скори крај човјека каквог познајемо и долазак „пост-хуманог“ човјека. Каквог је карактера промјена оА старог ка новом човјеку коА Павца и у трансхуманизму? Постоји ми континуитет ьудског идентитета у тој промјени? Не угрожава $\Lambda$ иа промјена ьудско достојанство? ОАговор на ова питања условњен је постојањем неке нормативне слике човјека сходно којој се „стари човјек“ преображава и обнавља у „новог човјека“, на основу чега би постојао критеријум истинског ьудског побољшања и напредовања.

У Павцовој антропологији ту нормативну слику човјека пројавьује Богочовјек који је у себи сјединио божанску и ьудску природу. Творећи „богочовечанску новину“ Богочовјек је открио и „новог човјека“ као норму са којом се човјек саображава, самим тим преображава и обнавља. ${ }^{12}$ Човјечанска Аимензија, тј. ьудски идентитет у тој егзистенцијалној динамици и промјени ипак не бива укинут, ни када Павле каже: „Са Христом се разапех. А живим не више ја него живи у мени Христос; а што саА живим у тијеку, живим вјером Сина Божијега, који ме заволи и предаде Себе за мене (Гал. 2, 20)“. Ова Аинамика кретања од старог ка новом човјеку не одвија се на механички начин, она није спова наметнута, већ је ствар човјековог мичног животног подвига којим човјек „узраста до Бога“. ${ }^{13}$ Са старим човјеком не умире и оно ьудско као такво, него се „свлачи“ и одбацује оно грјеховно и смртно као извор сваког ограничења у човјеку.

\footnotetext{
9 Peters, "Progress and Provolution", 64.

${ }^{10}$ Rölli, "Einleitung”, 7.

11 Waters, "Whose Salvation? Which Eschatology?", 169; Schmaus, "Nietzsches letzter Mensch als transhumanistische Dystopie".

12 Јевтић, „Стари и нови човек у Цркви“, 195.

${ }^{13}$ Јевтић, „Стари и нови човек у Цркви“, 201-202. ВАадика Атанасије скреће пажњу на Павлову мексику,

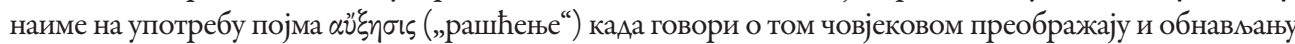
као „рашћењу растом Божијим“ (Eф. 4, 15-16; Кол. 2, 19). Аакле, не ради се о механичком процесу већ о промјени која долази из унутрашње димензије човјекове Аичности.
} 
У трансхуманизму, који категорички засупа примјену технологије за „ьуАско побољшање“ Аоводи се у питање, не само континуитет Аичног већ и ьудског идентитета као таквог, а крајње је спорно и постојање неке нормативне слике човјека или нормативног појма ьудске природе сходно којем би се човјек саображавао у настојању да побољша своју биолошки дефицијентну природу. Штавише, појам ьудске природе има негативне конотације и више не игра укогу нормативног појма, као у хришћанској антропомогији и у тзв. „биоконзервативизму“ који представња интелектуалну опозицију трансхуманизма. ${ }^{14} \mathrm{У}$ најбољем скучају, за трансхуманистички пројекат важи парадоксалан став Хермана Броха да „(ч)овјек може порицати постојање Бога, али никада неће порећи Аа је његова сопствена вјерна слика“, 15 шта гоА то подразумијевало. Стога, технолатријски ентузијазам трансхуманизма и вјера у свемоћ технологија ьудског побовшања прије води у човјеково самоукидање, него што му омогућава афирмацију мичног и ьудског идентитета на нов начин. Стога се сасвим оправдано намећу подједнако неповољне претпоставке за трансхуманистичке заговорнике технолошког интервенисања на ьудској природи. Технолошка трансформација ьудског сопства не може ни дотаћи човјекову „предиспозицију ка гријеху који вреба у нама, а прије свега ни нашу чежњу за јединством са божанском стварношћу“. ${ }^{16}$ Технологија је нешто „сувише ьудско“ Аа би могла Аа произведе толико радикалну трансформацију човјека, иако је крајњи циь трансхуманизма пост-хумани човјек, што је contradictio in adjecto трансхуманизма. Отуда, када говори о човјековом ,Ппобоњшању', трансхуманизам се уопште не односи на превазимажење себе, већ се у великој мјери односи на само-одржање, само-потврђивање, само-напредовање ${ }^{\text {"17 }}$ човјека. Тежећи постхуманој форми постојања путем технологије, трансхуманизам само потврђује оно хумано, штавише, трансхуманизам ренатурализује човјека, иако најавьује ослобађање човјека оА његове биомошке природе. Приступајући човјеку извана, као безмичној и пукој Аатости, трансхуманизам онемогућава истински преображај човјека који долази из дубине човјекове унутрашњости, из његове мичности. Трансхуманизам остаје везан за иманенцију, а истинска промјена и преображај човјека не може бити униматераман и аутономан подухват, већ је Ајемо

\footnotetext{
${ }^{14}$ О нормативном појму ьудске природе код трансхуманиста и биоконзервативаца види код Hauskeller, "Prometheus unbound".

${ }^{15}$ Broh, Misli o politici, 187.

${ }^{16}$ Cole-Turner, "Introduction", 9.

${ }^{17}$ Babich, "Nietzsche’s Post-Human Imperative", 116.
} 
синергије, садејства и сусрета божанског плана и ьудске слободе. Павлово схватање човјековог испуњења у учествовању у пуноћи божанског живота и у ступању у зајеАничарење са Богом преАставьа примјер „синергијске антропологије“ у православној традицији, за размику оА трансхуманизма који је типичан изданак западноевропске традиције „аутономне антропологије“. 18

Обезвређујући нормативни појам ьудске природе, самим тим и тјемесно-душевно-Ауховни скмоп човјека као творевине Божије, савремени трансхуманизам преАставьа не само теоријски изазов већ и изазов за ьуАско достојанство, утолико што човјека посматра као сирову грађу на којој се испољава технолошка моћ у циьу човјековог редизајнирања готово без икаквих ограничења. Опчињен технолошким моћима, трансхуманизам не увиђа Аа се управо у рањивости, крхкости и недовршености ьудске природе, у коју је утиснут мик Творца, нацази разликовно обиьежје човјека, његов посебан положај унутар творевине и његово достојанство. Након свега, можемо закьучити да за савремени научно-технолошки комплекс, чији напредак инспирише покрете попут трансхуманизма и његову идеју технолошког побољшања човјека, Павлови Аубоки увиди о Аинамици кретања од старог ка новом човјеку преАстављају незамјеньив коректив који упозорава на опасност духовног осиромашења савременог човјека и губитка његовог контакта са свијетом живота и зајеАницом са другим ьудима.

${ }^{18}$ Синтагме преузимамо оА Kantartzis, "Mariology, Anthropology, Synergy and Grace”. 


\section{Библиографија}

Амфилоије, Митрополит, „Суочавање божанске и ьудске егзистенције“, у: Id., Очовјечени Бог, обожени човјек, Изабрана дјела Архиепископа Цетињског и Митрополита Црногорско-приморског Амфимохија (Радовића), књ. V, Цетиње: Светигора, 2019

Babich, Babette, "Nietzsche's Post-Human Imperative: On the 'All-too-Human' Dream of Transhumanism", in: Yunus Tuncel (ed.), Nietzsche and Transhumanism: Precursor or Enemy?, Newcastle: Cambridge Scholars Publishing, 2017, 101-132.

Broh, Herman, Misli o politici, Beograd: Filip Višnjić, 2000

Cole-Turner, Ronald, "Introduction: The Transhumanist Challenge", in: Id. (ed.), Transhumanism and Transcendence: Christian Hope in an Age of Technological Enhancement, Washington, DC: Georgetown University Press, 2011, 1-18.

Delahaye, Ezra, “The Philosophers' Paul: A Radically Subversive Thinker”, in: Gert Jan van der Heiden, George Henry van Kooten, Antonio Cimino (eds.), Saint Paul and Philosophy. The Consonance of Ancient and Modern Thought, Boston: De Gruyter, 2017, 81-93.

Hauskeller, Michael, "Prometheus Unbound: Transhumanists Argument from (Human) Nature", Ethical Perspectives, 16:1, 2009, 3-20.

Heil, Reinhard, “Trans- und Posthumanismus. Eine Begriffsbestimmung”, in: Annette Hilt, Isabella Jordan, Andreas Frewer (Hrsg.), Endlichkeit, Medizin und Unsterblichkeit: Geschichte-TheorieEthik, Wiesbaden: Franz Steiner Verlag, 2010

Јевтић, Атанасије, „Стари и нови човек у Цркви“, Богословље, 1985, 185-204.

Kant, Immanuel, „Odgovor na pitanje: Što je prosvjetiteljstvo?“, u: Id., Pravno-politički spisi, Zagreb: Politička kultura 2000, 33-42.

Kantartzis, Panagiotis, "Mariology, Anthropology, Synergy and Grace: Why Is Luther So Far Apart from Cabasilas?”, Religions, 12:5, 2021, 343.

Niče, Fridrih, Sone strane dobra i zla, Beograd: Grafos, 1983

Niče, Fridrih, Tako je govorio Zaratustra, Podgorica: Oktoih 1998

Peters, Ted, "Progress and Provolution. Will Transhumanism Leave Sin Behind?", in: Ronald ColeTurner (ed.), Transhumanism and Transcendence: Christian Hope in an Age of Technological Enhancement, Washington, DC: Georgetown University Press, 2011, 63-86.

Rölli, Marc, "Einleitung”, in: Marc Rölli, (Hrsg.) Fines Hominis? Zur Geschichte der philosophischen Anthropologiekritik, Bielefeld: Transcript Verlag, 2015, 7-16.

Schmaus, Thomas, "Nietzsches letzter Mensch als transhumanistische Dystopie”, in: Helmut Heit, Sigridur Thorgeirsdottir (Hrsg.), Nietzsche als Kritiker und Denker der Transformation, Berlin: De Gruyter, 2016, 206-221.

Вишеславцев, Борис, Вечно у руској философији, превео А. Аранитовић, БеограА: Аогос, 2007

Waters, Brent, "Whose Salvation? Which Eschatology? Transhumanism and Christianity as Contending Salvific Religions", in: Ronald Cole-Turner (ed.), Transhumanism and Transcendence: Christian Hope in an Age of Technological Enhancement, Washington, DC: Georgetown University Press 2011, 163-175. 